\title{
OS CONTRASTES DE CIÇA: EXPLORANDO OS ETHÉ DA CARTUNISTA BRASILEIRA
}

\author{
Ciça's Contrasts: Los contrastes de Ciça: \\ Exploring the Ethé of the explorando los ethé \\ Brazilian Comic Book Artist de la dibujante brasileña
}

Ana Cristina Carmelino*

Paulo Ramos**

Universidade Federal de São Paulo, Escola de Filosofia, Letras e Ciências Humanas, Departamento de Letras, Guarulhos, SP, Brasil

\begin{abstract}
Resumo: O objetivo deste artigo é mostrar a construção dos ethé de Ciça, cartunista que se tornou conhecida pela série de tiras cômicas de $O$ Pato, publicada durante os anos da Ditadura Militar brasileira (1964-1985) no jornal Folha de S.Paulo. Embora seja considerada uma das principais desenhistas de histórias em quadrinhos do Brasil, não há muitas referências a ela, dado que justifica este artigo. Os pressupostos teóricos que fundamentam a análise advêm da Retórica e Nova Retórica, especialmente a partir da noção de ethos, que constitui a imagem que orador constrói de si e dos outros no discurso. Como corpus de estudo, são utilizados principalmente textos de apresentação presentes em suas obras e entrevistas concedidas pela cartunista.
\end{abstract}

Palavras-chave: Retórica. Ethos. Cartunista. Ciça.

\begin{abstract}
The purpose of this paper is to show the construction of Ciça's ethé, a comic book artist who became known for the comic strips series O Pato (The Duck), published in the newspaper Folha de S.Paulo during the Brazilian Military Dictatorship (1964-1985). There are not many references about her, although considered one of the main comic book artists in Brazil, information that justifies this study. The theoretical assumptions that support the analysis come from Rhetoric and New Rhetoric, especially the notion of ethos, which constitutes the image that speakers build of themselves and others in the discourse. As corpus of study, we particularly use the presentation texts in her works and interviews given by the artist herself.
\end{abstract}

Keywords: Rhetoric. Ethos. Comic book artist. Ciça.

Resumen: El propósito de este artículo es mostrar la construcción de los ethé de Ciça, una dibujante que se hizo conocida por la serie de tiras cómicas de $O$ Pato, publicada durante los años de la Dictadura Militar brasileña (1964-1985) en el periódico Folha de S.Paulo. Aunque sea considerada una de las principales dibujantes de los cómics en Brasil, no hay muchas referencias a ella, información que ya justificaría este artículo. Los supuestos teóricos que subyacen al análisis provienen de la Retórica y la Nueva Retórica, especialmente de la noción de ethos, que constituye la imagen que el hablante construye de sí mismo y de los demás en el discurso. Como corpus de estudio, se utilizan principalmente textos de presentación existentes en sus obras y entrevistas concedidas por la dibujante.

Palabras-clave: Retórica. Ethos. Dibujante. Ciça.

* Docente do Departamento de Letras. ORCID: https://orcid.org/0000-0002-7576-0595. E-mail: anacriscarmelino@gmail.com.

** Docente do Programa de Pós-Graduação em Letras. ORCID: https://orcid.org/0000-0002-9348-4176. Email: contatopauloramos@gmail.com 
Há um contraste em torno da cartunista Ciça: ao mesmo tempo que é creditada como uma das principais desenhistas de histórias em quadrinhos do Brasil, nota-se que tem pouca projeção, seja nos compêndios (enciclopédias, dicionários e antologias) de humor gráfico ou quadrinhos de autores nacionais, seja no meio acadêmico. No primeiro caso, os autores tendem a reprisar quase sempre a mesma nota: ela produziu tiras cômicas de "O Pato" para a Folha de S.Paulo durante quase 20 anos, período em que teve de criar sob o fantasma do regime militar (1964-1985) - a ditadura era trabalhada de forma metafórica em muitas de suas narrativas de humor ${ }^{1}$.

No segundo caso, identifica-se comportamento semelhante. Encontram-se poucos artigos a respeito da desenhista. Dantas (s. d.) registra o jornal onde publicou a série "O Pato". Silva (2013) dá noção rápida sobre ela, observando sua inserção no humor gráfico produzido por mulheres. Santos (2019) menciona que o traço simples ajudava a tornar o conteúdo (como repressão política e crise econômica) disfarçado aos olhos dos censores. Os artigos científicos sobre Ciça menos econômicos talvez sejam os de Crescêncio (2016, 2017, 2018) e de Crescêncio e Dantas (2019), tendo em vista que as autoras estudam produções gráficas humorísticas feitas por mulheres cartunistas e veiculadas em jornais com viés feminista, para os quais a desenhista desenvolveu a personagem "Bia Sabiá".

Embora os registros sobre Ciça não deixem a história da autora passar em branco, são bastante modestos dada a relevância, inclusive histórica, atribuída a ela e ao conteúdo produzido sobre a desenhista. A discussão se torna ainda mais relevante quando se somam os fatos de que Ciça produziu histórias em um momento histórico em que o mercado era duplamente contrário às mulheres. Primeiro por o mercado de trabalho no setor gráfico ser majoritariamente dominado por autores homens. E segundo por isso ocorrer em um cenário em que eles também sofriam para se colocar, posto que a maioria do conteúdo publicado era estrangeiro, principalmente dos Estados Unidos.

Mesmo com essas duas adversidades - o domínio quase total do mercado por homens e o interesse por conteúdo estrangeiro -, a criadora de "O Pato" conseguiu se inserir. Nas referências a ela em livros e artigos, reconhecem-se justamente esses aspectos, embora em registros modestos. Desse modo, este artigo procura contribuir para a criação de um registro um pouco mais detalhado sobre as imagens construídas da (e sobre a) autora. A partir do reconhecimento do papel de protagonista dela na trajetória do humor gráfico nacional, procura-se reforçar a inserção da desenhista no (necessário) circuito de pesquisas científicas, tendo em vista também sua relevância na história das mulheres e dos quadrinhos no Brasil. $\mathrm{O}$ aspecto central a ser explorado é a construção dos ethé de Ciça. Logo, questiona-se: quais são os ethé de uma das cartunistas que protagonizaram o humor gráfico no país?

\footnotetext{
${ }^{1}$ Podem ser citadas as obras Antologia brasileira de humor (1976), Literatura em quadrinhos no Brasil, o acervo da Biblioteca Nacional (MOYA; CIRNE, 2002, p. 134), História da história em quadrinhos (MOYA, 1993, p. 194), Enciclopédia dos quadrinhos (GOIDANICH; KLEINERT, 2011, p. 95), única que inclui outra série de Ciça, "Bel", Humor em pílulas: a força criativa das tiras brasileiras (MAGALHÃES, 2006, p. 54-55) e Mulheres e quadrinhos: universidade (MARINO; MACHADO, 2020), obra que traz quatro menções à autora, aludindo a ela ser uma das precursoras dos quadrinhos.
} 
Para isso, são acionados pressupostos da Retórica (ARISTÓTELES, 2015; 1996) e da Nova Retórica (PERELMAN; OLBRECHTS-TYTECA, 1996; AMOSSY, 2005; MEYER, 2007; FERREIRA, 2010, 2019). A exposição pretende demonstrar como se constitui a imagem dela (ou do orador, conceito vinculado a esse escopo teórico) por meio de si mesma e pelo olhar dos outros. O corpus é composto por quatro entrevistas disponíveis da desenhista nos meios digitais e impressos, assim como textos introdutórios de suas obras publicadas em forma de livro. Trata-se do pouco material existente que, em contraste com as produções acadêmicas, acrescenta alguns elementos sobre a trajetória e o pensamento da autora.

\section{O ETHOS SOB O VIÉS DA RETÓRICA E DA NOVA RETÓRICA}

A Retórica é entendida aqui "como uma arte e, simultaneamente, como um conjunto de técnicas argumentativas de que o orador se vale para angariar 'autoridade' por meio de sua voz" (FERREIRA, 2019, p. 11). Sua eficácia se consolida quando um orador consegue imprimir ao dizer o seu poder de influência, dado que está diretamente relacionado à demonstração de personalidade e caráter de quem fala, ou seja, à apresentação do orador - e a representação (ethos) que ele constrói - diante de ouvintes ou leitores.

O conceito de ethos, especificamente sob a ótica do campo da Retórica, provoca um debate que dura séculos - se levarmos em conta a trajetória de como a noção era concebida e tratada na Filosofia Antiga até constantes releituras dela feitas contemporaneamente. Apesar de Aristóteles não ter sido o primeiro a cunhar o termo, pode-se dizer que foi quem esboçou as premissas centrais de como o ethos viria a ser trabalhado.

De acordo com Aristóteles (2015), os discursos mobilizam três dimensões em sua constituição. A primeira seria a do orador, referente à dimensão do ethos. Este consiste na imagem que ele projeta de si, em seu discurso, seja ela verdadeira ou não, para convencer e persuadir seu auditório. A segunda dimensão seria a do pathos, que se centra no auditório e corresponde às emoções (paixões) por ele manifestadas (mas que são incitadas pelo orador). A terceira concerne ao $\log o s$, que se refere à argumentação utilizada, ou seja, à produção do discurso em si.

O ethos - visto por muitos estudiosos como a mais importante das provas retóricas, capaz de tornar o discurso persuasivo - está vinculado a um conjunto de traços de caráter que o orador mostra ao auditório para causar boa impressão de si e ganhar a sua confiança (ARISTÓTELES, 2015, 1996). O ethos, cumpre salientar, deriva do discurso, já que "persuade-se pelo caráter quando o discurso é proferido de tal maneira que deixa a impressão de o orador ser digno de fé [...] porém, é necessário que esta confiança seja resultado do discurso e não de uma opinião prévia sobre o caráter do orador" (ARISTÓTELES, 2015, p. 63).

Sobre os traços responsáveis por tornarem os oradores persuasivos, esses seriam: a) a prudência (phrónesis), b) a virtude (areté), c) a boa vontade (eúnoia). Detalhando um pouco cada um deles, pode-se dizer que a phrónesis corresponde à sensatez, à ponderação, 
à sabedoria prática, ao bom senso; por se colocar entre as virtudes e os vícios (cf. ARISTÓTELES, 1996), mostra um orador capaz de exprimir opiniões competentes e razoáveis. A areté, que denota a virtude, é a disposição que leva o (bom) orador a realizar sua função com honestidade, manifestando sinceridade, simplicidade, coragem. Já a eúnoia, relacionada à benevolência e à solidariedade, exibe um orador simpático, com a apresentação de uma imagem agradável de si.

A Nova Retórica, que surge das teorias da argumentação propostas no final da década de 1950, amplia e ressignifica a noção de ethos. Esta passa, na visão contemporânea, a ser vista como a "imagem que o orador constrói de si e dos outros no interior do discurso" (FERREIRA, 2010, p. 90), ou, como registram Perelman e Olbrechts-Tyteca (1996) e Amossy (2005), a uma construção do discurso em que o orador passa a moldar sua fala conforme os valores que ele crê valorizados por seu auditório.

Meyer (2007, p. 35), sob o viés da problematologia, propõe uma noção mais moderna de ethos, ao defender que essa prova não pode ser pura e simplesmente identificada ao orador: "O ethos é um domínio, nível, uma estrutura", no entanto "não se limita àquele que fala pessoalmente a um auditório, nem mesmo a um autor que se esconde atrás de um texto". Para o autor, o ethos se apresenta "como aquele ou aquela com que o auditório se identifica, o que tem como resultado conseguir que suas respostas sobre a questão tratada sejam aceitas" (MEYER, 2007, p. 35).

O filósofo belga ainda propõe uma distinção entre o que chama de ethos projetivo e ethos efetivo: o ethos imanente ou projetivo corresponde à "projeção da imagem que deve ter o ethos aos olhos do pathos" (MEYER, 2007, p. 35), ou seja, é a imagem que, a priori, tanto o orador quanto o auditório projetam entre si; já o ethos efetivo ou nãoimanente diz respeito à imagem realmente construída pelo orador, visando persuadir o auditório, e que seria, portanto, efetiva.

Considerando-se as disposições ou virtudes morais tratadas por Aristóteles (1996), na obra Ética a Nicômaco, é possível pensá-las como representações - ou em ethé, como o faz Carmelino (2018). Segundo o filósofo, a virtude moral seria o equilíbrio (meiotermo) entre dois vícios: o excesso e a ausência (carência). A exemplo, podemos considerar que, em relação ao ato de divertir/provocar riso, o virtuoso seria o espirituoso, espécie de mediania por se distanciar dos extremos, que seriam: o excessivo chocarreiro/bufão e o deficiente rústico, sem senso de humor algum (ARISTÓTELES, 1996).

Ao refletir sobre as disposições aristotélicas, Mendes (2008) observa que elas podem ter inspirado a classificação dos tipos cômicos da comédia, conhecidos como: o impostor ou fanfarrão (alazón), o ironista ou autodepreciador (eíron) e o bufão (bomolóchos). Frye (2013) inclui mais um a esses tipos: o ágroikos (o rústico ou camponês). Carmelino (2018) propõe uma articulação entre as características cômicas estabelecidas tanto por Aristóteles quanto por Mendes e Frye. Tais marcas, segundo Carmelino, evidenciam imagens de cada um desses tipos cômicos, a partir das quais se pode chamar de ethé cômico.

É o que se observa na citação que segue: 
a) alazón: alguém que finge ou tenta ser mais do que é; caracteriza-se pela confiança e otimismo desmedido, mas também pela ausência de conhecimento próprio; conforme Frye (2013: 153) - em sua "teoria dos mitos", que vai da tragédia à comédia - na tragédia, o alazón representaria o erudito excêntrico, o filósofo obcecado, o cientista maluco, o intelectual pedante; na comédia, seria o esperto, o carismático e sem escrúpulos, espécie de patife;

b) eíron: caracterizado pela crítica e pela desconfiança; é o que costuma censurar e se autocensurar, desvelando, em geral, os excessos e a impostura do alazón; em geral é o personagem que se mostra como herói inocente (autocensura) ou como superior (censura os outros, desmascarando-os) (Frye 2013; Mendes 2008);

c) bomolóchos: personagem com espirituosidade demais; exalta a comicidade; tais traços são reconhecidos em palhaços, pajens ou qualquer outra figura secundária que tenha o objetivo de conseguir o entretenimento da audiência (Frye 2013); Mendes (2008: 155) observa que se trata de um tipo insano, incongruente;

d) ágroikos: opõe-se ao bomolóchos, pois apresenta espirituosidade de menos; é reconhecido pela ausência de senso de humor; esse tipo cômico está presente em personagens que exibem traços de ingenuidade, simplicidade ou até mesmo ignorância (Frye 2013; Mendes 2008). (CARMELINO, 2018, p. 86)

Em síntese, considera-se o ethos a construção de um perfil social de si, o qual inclui as atitudes, os costumes, a moralidade - elementos que aparecem na disposição do orador e que constituem sua historicidade. Como bem lembra Ferreira (2019, p. 21), o ethos é

\begin{abstract}
uma dimensão construída do orador e pelo orador, que, por ser humano, possui um passado conhecido ou não, um presente em que demonstra ou não competência oratória e um futuro que se sustenta a partir dos efeitos de sentidos obtidos em um ou mais atos retóricos precisados temporal e espacialmente, responsáveis pela promoção e manutenção do "status" que se atribui a um sujeito-orador.
\end{abstract}

\title{
3 A CARTUNISTA CIÇA: BREVE CONTEXTUALIZAÇÃO
}

Cecília Whitaker Vicente de Azevedo Alves Pinto, ou simplesmente Ciça, como assina suas produções gráficas, além de quadrinista, é também escritora, jornalista, poetisa, artesã, artista, ilustradora, dona de casa (cf. CIÇA, 1986, capa). Nascida em São Paulo, capital, em 2 de maio de 1939, a desenhista mudou-se com a família para o Rio de Janeiro, aos 13 anos, cidade onde morou entre as décadas de 1950 e 1970.

Segundo a própria cartunista, no Rio conviveu desde cedo com diferentes artistas (figuras da música, da literatura, do jornalismo e da política), porque um de seus tios era diretor da revista $O$ Cruzeiro: "a casa dele era um polo e nós morávamos no mesmo prédio [...] eles iam lá confabular” (CRESCÊNCIO, out. 2019). Nesse meio, Ciça fez política estudantil (participava dos movimentos da UBES - União Nacional dos Estudantes Secundaristas) e se tornou amiga de Millôr Fernandes e Ziraldo, dupla que produzia humor (cf. MORAES; SEVERINO, 21 fev. 2020).

Em 1963, casou-se com Zélio Alves Pinto (irmão de Ziraldo), também jornalista e artista plástico e gráfico, com quem teve três filhos. No início da década seguinte, retornou a São Paulo, onde reside desde então. A capital paulista só foi substituída por um período de sete anos, na década de 1980, quando morou nos Estados Unidos².

\footnotetext{
${ }^{2}$ As informações podem ser conferidas em: MAIS Malditos Cartunistas - Ciça, YouTube, 16 abr. 2018. Disponível em: https://www.youtube.com/watch?v=ArzBZOdxayI.
} 
No que concerne à sua produção, entre poesias, quadrinhos e livros infantojuvenis, Ciça soma mais de trinta publicações (BORGES; ZOUVI, jan/fev. 2020). De acordo com a artista, ela começou a desenhar e a escrever quando tinha 18 ou 19 anos: fez desenhos (e ilustrou matérias) para $O$ Cruzeiro e publicou alguns contos n' $O$ Pasquim. No entanto, a primeira produção de humor gráfico, uma criação própria, foi para o suplemento "Sol" do Jornal dos Sports, um diário de notícias do Rio de Janeiro, publicado de 1931 a 2010.

A proposta era refletir sobre problemas cotidianos da população, voltando a atenção para temas criticáveis via bom-humor e ironia, casos de corrupção, economia, consumismo, problemas do cotidiano, repressão, movimento sindical, machismo, brigas conjugais. Para abordar tais temas, a opção foi desenhar bichos: começa com uma família de galináceos [galo (Hermes), galinha (Naná), pintinhos, pato, pata (Filomena)], mas o universo é ampliado com o tempo, já que nas histórias se observam outros animais, como cobra (Salomé), sabiá (Bia Sabiá), caracol (Bólido Barbosa), pomba, pavão, sapo, ticotico, joão-de-barro, gambá, borboleta (BORGES; ZOUVI, jan/fev. 2020; CRESCÊNCIO, out. 2019; Lady's Comics, 30 jan. 2014).

Convém destacar que Ciça passou a ser conhecida como quadrinista após publicar suas tiras e cartuns na Folha de S. Paulo, jornal que veiculou sua produção de humor gráfico diariamente durante quase 20 anos. A sua criação mais famosa é a tira intitulada "O Pato", impressa pela primeira vez em 19 de novembro de 1967 e encerrada em 21 de novembro de 1985. Depois de um período de 35 anos, "O Pato" é retomado pontualmente na edição da Folha de 23 de fevereiro de 2020. Dado que ajuda a reforçar a relevância da série.

Embora caracterizada como um desenho simples, a série "O Pato" mostrava a força crítica, bem como a consciência política da autora: os personagens utilizavam-se de metáforas para criticar o cenário político do país. O viés político, cumpre destacar, aparece principalmente concentrado nas tiras publicadas em $O$ Pato no formigueiro (1979), na qual o formigueiro retrata o país na época. É o que se observa nos exemplos que seguem.

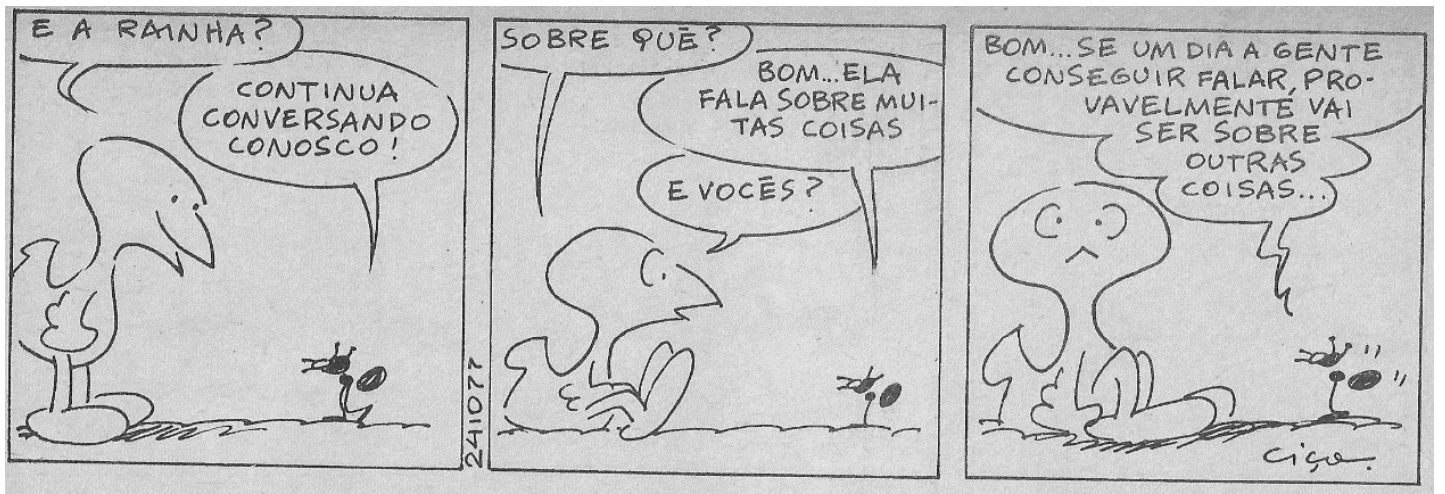

Figura 1 - 0 Pato

Fonte: CIÇA. O pato no formigueiro. Rio de Janeiro: Codecri, 1979, p. 24.

Na Figura 1, o pato é mostrado em contato com uma das formigas. Pergunta sobre a rainha. Ouve como resposta que esta continuaria conversando com elas. "Sobre quê?". 
"Bom... ela fala sobre muitas coisas", retruca. A surpresa, como é próprio de tiras cômicas como essa, é revelada na cena final. Ao contrário do que se esperaria, a rainha revela um comportamento autoritário, evidenciado pelo monólogo. Quem explica é a própria formiga: "Se um dia a gente conseguir falar, provavelmente vai ser sobre outras coisas...".

Na proposta de Ciça, conforme destaca Silva (2013), a formiga-rainha simboliza o governo autoritário, as formigas-operárias representam o povo, ora revoltado e buscando saídas para o problema, ora acomodado e cooptado pela situação; as formigas-deputados são os asseclas que apoiam e legitimam os desmandos do governo. A metáfora foi retomada pela autora décadas depois, quando foi convidada a produzir uma tira de "O Pato" para o jornal que ajudou a popularizar a série. Mas agregando outros referentes. A história foi publicada no dia 23 de fevereiro de 2020, na capa da Folha de S.Paulo". Nesse momento histórico, o país era governado por Jair Bolsonaro, que iniciava seu segundo ano de mandato.

Nessa produção mais recente de Ciça, a cartunista coloca em diálogo uma vez mais o Pato e a formiga. Esta pergunta se ele saberia "qual a diferença do nosso formigueiro e a Inglaterra?". Ela mesma responde: "Lá eles têm uma rainha que reina e um governo que governa". "E aqui?", replica o interlocutor, em questionamento necessário para levar ao desfecho de humor. "Aqui a gente tem uma rainha, três filhos de rainha, uma dúzia de generais e um astrólogo que reinam e ninguém governa".

Mudam-se os governos, mudam-se os referentes. A alusão codificada aos personagens reais do cenário político brasileiro de 2020 era a retomada de uma estratégia usada pela autora décadas antes para contornar a censura que vigorava no país durante os anos do regime militar, período em que a série era publicada, da estreia em 19 de novembro de 1967 à derradeira história no jornal, com direito até a despedida, em 21 de novembro de 1985.

De acordo com Ciça, por meio de seus bichos (o pato, as formigas, especialmente), ela "podia 'falar' mais à vontade sobre a ditadura". Acrescenta ainda que, "no caso da repressão, acredito que os bichos me ajudaram, pois as autoridades da época provavelmente preferiam não admitir que estavam sendo representados por um pato, ou um sapo, ou uma formiga usando quepe militar" (BARALDI, 18 jul. 2007), ou seja, não se sentiam "à vontade para assumir a identificação pública com um inseto insignificante" (MORAES; SEVERINO, 21 fev. 2020). O mesmo recurso é usado pela cartunista atualmente.

Além da Folha de S.Paulo, a artista também publicou seus quadrinhos em outros jornais nacionais (Pasquim, Jornal do Brasil) e internacionais (Suécia, África do Sul, Inglaterra, França ${ }^{3}$, bem como colaborou com a imprensa alternativa, especialmente voltada ao papel das mulheres na sociedade, caso dos jornais feministas Nós Mulheres (São Paulo, 1976-1978), Brasil Mulher (Londrina/São Paulo, 1975-1980) e Mulherio (São Paulo, 1981-1988). Da vasta produção, vem o mérito: em 2009, recebeu o $21^{\circ}$ Troféu HQ Mix na categoria "Grande Mestre" e, em 2019, ganhou o Troféu Angelo Agostini, por meio de votação popular, na categoria "Mestres do Quadrinho Nacional"4.

${ }^{3}$ As informações podem ser conferidas em Ziraldo (1978, p. 3) e Crescêncio (out. 2019).

4 Os dados da premiação de Ciça podem ser constados nos seguintes sites: https://pt.wikipedia.org/wiki/Trof\%C3\%A9u_HQ_Mix e http://www.universohq.com/noticias/veja-osvencedores-do-trofeu-angelo-agostini-2019/. 
Sabemos que, ao enunciar, o orador pode tanto revelar imagens de si quanto do(s) outro(s) no discurso. Desse modo, o leitor ou ouvinte constrói uma representação do orador por meio daquilo que ele diz e de sua maneira de dizê-lo. Nesta seção, buscamos mostrar quais são as imagens ou ethé construídos para Ciça, seja por ela mesma, a partir de algumas entrevistas concedidas por ela, seja por outros, a partir de apresentações da artista e de suas obras. Desse modo, os dados serão dispostos de modo a abarcar essas duas abordagens.

A título de esclarecimento, os enunciados foram depreendidos especificamente a partir de quatro entrevistas que, em nosso entender, são as mais consistentes sobre a artista.

É importante registrar, no que concerne a essas entrevistas tomadas como fonte de reflexão (embora o dado não interfira na construção dos ethé de Ciça), que os objetivos que as motivaram são distintos. A publicada no site Ladys Comics (30 de janeiro de 2014) demonstra que a nova geração de cartunistas está preocupada com a memória das cartunistas mulheres. A divulgada no periódico acadêmico Revista de Estudos Feministas (11 de abril de 2017) busca projetar Ciça, dada sua relevância, para a história das mulheres e do feminismo no Brasil, na academia. $\mathrm{O}$ depoimento foi concedido à pesquisadora Cintia Lima Crescêncio.

A entrevista de Ciça a Márcio Baraldi para o Bigorna (18 de julho de 2018), site criado com o objetivo de divulgar e valorizar as Histórias em Quadrinhos produzidas no Brasil e os profissionais da área, caso de roteiristas, desenhistas e editores, visava a divulgar o lançamento da obra Pagando o Pato pela editora L\&PM, o que significava o retorno de Ciça ao mercado de Quadrinhos. Já a entrevista publicada na Banda (janeiro e fevereiro de 2020), revista bimestral sobre quadrinhos, tinha como objetivo trazer em foco a discussão entre quadrinhos e política no Brasil. O interesse na cartunista era por ela ter produzido suas tiras durante a Ditadura Militar, época marcada por censura, violência e intolerância. As perguntas à cartunista foram feitas por Thiago Borges e Aline Zouvi.

\subsection{IMAGENS QUE CIÇA CONSTRÓI DE SI}

A análise de algumas entrevistas cedidas por Ciça ao longo de sua vida permite verificar que ela constrói diferentes ethé de si. Embora alguns sejam mais recorrentes ou marcantes, caso da cartunista (artista, intelectual) e humorista crítica e politizada, imagens que, certamente, a tornaram notória, é preciso esclarecer que são possíveis outras. Não custa reforçar que os enunciados destacados partem de uma oradora que tem discurso autorizado, já que se trata de "um dos principais nomes do humor gráfico nacional" (CRESCÊNCIO, out. 2019).

Consideramos, juntamente com Amossy (2005), que o orador não precisa fazer seu autorretrato, detalhar suas qualidades nem falar explicitamente de si para desvelar seu ethos (imagens de si), basta que ele tome a palavra. Desse modo, dos discursos (logos), é 
possível observar diferentes ethé construídos pela própria Ciça em sua enunciação, ou projetados por ela, nos moldes de Meyer (2007). Para mostrá-los, consideram-se as várias atuações (ou atividades) exercidas por ela, suas competências e crenças.

Comecemos com a Ciça cartunista, que se revela espontânea, metafórica, crítica, politizada, desvalorizada financeiramente e requisitada. A espontaneidade (simplicidade) e a metáfora podem ser vistas quando a artista comenta sobre o estilo (o que pensa) de seus desenhos, cuja preocupação não era com algo bem elaborado, bonito, mas, sim, linear, artesanal, metafórico: "Eu estava começando mesmo e eu escolhi fazer com animais, com pato, galinha, pintinhos. Funcionou porque eu tinha uma veia que não era bonitinha [...] não gosto de bonitinho [...] era quase que artesanal" (CRESCÊNCIO, out. 2019) e "Meus desenhos são bem lineares [...] Eu falava, mas com metáfora" (BORGES; ZOUVI, 2020, p. 18, p. 20).

Ao falar sobre os assuntos abordados em suas tiras e cartuns, revela-se crítica e politizada: "Meus temas sempre foram comportamentais e sobretudo comentários críticos sobre política e cotidiano" (ENTREVISTA - Ciça, 30 jan. 2014); "Mesmo em meus quadrinhos, é mais a posição política, a crítica, do que propriamente o desenho" (BORGES; ZOUVI, 2020, p. 18).

Em termos do reconhecimento de seu trabalho como cartunista, mostra-se desvalorizada financeiramente ["Todo mundo que me contatava e, se eu gostava de estar com o veículo, eu fazia. O trabalho das mulheres era de graça. E a Folha era quase de graça. Não era de graça, mas o pagamento era ridículo. Nos jornais em que eu trabalhava, eu recebia o exemplar" (CRESCÊNCIO, out. 2019); "Nunca senti preconceito por ser uma cartunista mulher. Sentia mais uma desvalorização em geral do trabalho de cartunistas e quadrinistas"” (Lady's Comics, 30 jan. 2014)], porém valorizada socialmente ["eu era muito convidada pra falar em colégios, em universidades, para professores. E tinha algo favorável àquela época, pois como era um período de repressão, na verdade eu falava o que as pessoas queriam falar, entendeu? (BORGES; ZOUVI, 2020, p. 20)].

A Ciça humorista, além de crítica, desvela-se irônica, tendo em vista que o humor produzido traz essas características. A crítica e a ironia são mostradas quando a artista diz que sua produção de quadrinhos "funcionou [...] porque eu tinha uma veia que [...] era mais irônica" (CRESCÊNCIO, out. 2019), "porque é mais a posição [...] crítica, do que propriamente o desenho [...] não dava pra deixar de fazer a crítica" (BORGES; ZOUVI, 2020, p. 18, p. 21).

Considerando-se a crítica social como um dos objetivos do humor (que pode ser política, de costumes, instituições, serviços, caráter, governo), visto que, com ela ou por meio dela, busca-se modificar a sociedade, mostrando "o absurdo e o ridículo de muitos comportamentos do homem, para que este veja a necessidade de romper com a estrutura social vigente" (TRAVAGLIA, 1989, p. 50), o ethos da humorista crítica também pode ser visto quando Ciça opina sobre como vê o humor:

\footnotetext{
O humor mostra não como as coisas devem ser, mas como as coisas não devem ser, sutilmente [...] é sempre contra. É sempre contra alguma coisa. Contanto que não seja contra o outro, rir da desgraça alheia. [...] Isso eu acho horrível, mas você mostrar como aquela atitude, aquela coisa que não é harmoniosa, que ela teria que ser diferente. Isso eu acho didático" (CRESCÊNCIO, out. 2019).
} 
Ainda no que tange às atuações da artista, a Ciça escritora mostra-se produtiva ("tenho mais de trinta livros publicados) e aplicada ("pesquisei muito"), conforme se constata em:

\begin{abstract}
Meu último livro que foi publicado [...] foi sobre a vida do Marechal Rondon [...] A gente tem tão poucos heróis nacionais que não acabam mal, né? [...] Eu fiz e ficou bonitinho, porque pesquisei muito nos diários dele [...] Ficou uma coisa bem ao alcance da meninada. Tenho mais de trinta livros publicados (BORGES; ZOUVI, 2020, p. 18).
\end{abstract}

Já a Ciça poetisa é sensível e verborrágica (ou de "textos longos", como ela mesma assinala): "Meus poemas são um pouco longos, mas aí vai um pequenininho, que eu gosto: 'Sol de montanha passando / (dia entre meias noites) / diáfano paralelo / sobre meu corpo, queimando. / Eu, linha, meridiano" (BARALDI, 18 jul. 2018).

Para Amossy (2005), as competências e as crenças (ideologias) são importantes para construir uma representação da pessoa. Nesse caso, ao explicitar que aprendeu "inglês lendo Quadrinhos" (BARALDI, 18 out. 2018), Ciça mostra-se autodidata. Em alguns de seus relatos, certas crenças e comportamentos revelam a artista como engajada e feminista; dados que podem ser observados nos seguintes enunciados:

\footnotetext{
[...] gostava de política o suficiente para fazer política estudantil, não me metia lá na União Nacional dos Estudantes (UNE) que era de estudantes formados, de universidade, mas tinha a União Nacional dos Estudantes Secundaristas (UBES) e eu estava lá" (CRESCÊNCIO, out. 2019)

Acho que meu viés político nasceu mesmo das circunstâncias. Eu era muito metida em política, era uma menina metida (risos). Não podia ser da UNE [União Nacional dos Estudantes] porque era estudante secundária. Então, participava da AMES, uma espécie de UNE do ginásio. Tava sempre lá fazendo o que os movimentos fizessem. Curtia isso. Acho que não tem muito a ver com as HQs (BORGES; ZOUVI, 2020, p. 19)

E se feminista é quem acha que mulher tem que ter direitos iguais aos homens, devo ser... (Lady's Comics, 30 jan. 2014)
}

Com exceção à profissional, pode-se falar também da Ciça caseira, cujas imagens reveladas são de uma pessoa simples, dedicada à família e sobrecarregada pelo trabalho doméstico. Em meio à produção assídua, ainda dispunha de tempo para cuidar dos entes próximos: "Eu tinha três filhos pequenos e tinha meu pai que esteve doente por muitos anos. Então, tinha muita coisa além do sentar e fazer" (CRESCÊNCIO, out. 2019). Em uma das entrevistas, declara que, quando o marido Zélio a ajudava com a arte-final dos desenhos, "tinha mais tempo para os filhos, os gatos, os cachorros, os passarinhos e até um galo e uma galinha que viraram os personagens Hermes e Naná" (BARALDI, 18 jul. 2018).

Com base nas disposições vistas em Aristóteles (2015, 1996), que tornam os oradores persuasivos a partir das imagens que exibem, verificamos que Ciça manifesta ethos de phrónesis, de areté e de eúnoia, isto é, apresenta as três características fundamentais a um bom orador: prudência, sinceridade e solidariedade. Ao falar de sua vida, posicionando-se quando é incitada, exprime opiniões competentes, mostrandosensata, ponderada. Exibe, portanto, phrónesis. É o que se verifica, por exemplo, quando diz que, embora o humor seja "sempre contra alguma coisa", não deve ser "contra o outro, rir da desgraça alheia” (CRESCÊNCIO, out. 2019). 
Nota-se que a oradora se revela sábia e inteligente ao refletir sobre a realidade. Um exemplo a mais que confirma sua sensatez é o que trata da forma como Ciça produzia as tiras após pedirem que pegasse leve na crítica: "Olha, eu regia fazendo um pouquinho diferente. Mas não dava pra deixar de fazer a crítica. Às vezes, eu até fazia uma coisa mais leve, mas no dia seguinte voltava com as formigas" (BORGES; ZOUVI, 2020, p. 21).

A cartunista se vale da areté quando exibe simplicidade e sinceridade ao expor seus pontos de vista, como se pode observar em "Eu gosto de fazer também bichinhos, mas nunca bonitinho, não gosto de bonitinho, eu gosto de uma coisa com humor" (CRESCÊNCIO, out. 2019)]. Por ser a virtude de quem conhece o que faz e o executa como resultado de uma disposição permanente, Ciça revela claramente o ethos de areté no trecho:

Eu faço histórias em quadrinhos: com quadrinhos, eu conto história. Neste livro [álbum especial, em que publicou suas tiras], entra a história dos fatos, circunstâncias e acontecimentos que me tocaram, me impressionaram, me divertiram, me indignaram, durante os últimos vinte anos em que estivemos todo pagando o pato (GOIDANICH; KLEINERT, 2011, p. 95).

A disposição para a eúnoia é percebida quando Ciça constrói uma imagem agradável de si, demonstrando simpatia, boa vontade. É o que se nota, por exemplo, no momento em que ela agradece a entrevista feita para o Bigorna: "Muito bom falar com o Bigorna também. Muito bom falar com quem peita um trabalho assim, tão bacana quanto difícil! Vocês é que são os verdadeiros super-heróis dos Quadrinhos!" (BARALDI, 18 jul. 2018). No exercício de ser e parecer do discurso, a generosidade, a condescendência, o altruísmo traduzem conformações de amizade característicos da eúnoia, como se nota no gesto simpático da cartunista.

Da caracterização dos ethé cômicos, conforme Carmelino (2018), que se baseia nos tipos de Aristóteles (1996), Mendes (2008) e Frye (2013), é possível reconhecer na humorista Ciça - e, consequentemente, em produções quadrinísticas - traços do ironista (eíron), já que a artista explicita, muitas vezes, essa tendência ao expor criticamente a realidade do país: a produção de quadrinhos "funcionou [...] porque eu tinha uma veia que [...] era mais irônica" (CRESCÊNCIO, out. 2019). Não só se autodefine como crítica - "sou muito crítica"; "não dava pra deixar de fazer a crítica" (BORGES; ZOUVI, 2020, p. 19, 21) -, como busca denunciar os excessos da política, reprovando a situação do país. Marcas do eíron.

\subsection{IMAGENS QUE OS OUTROS CONSTROEM DE CIÇA}

Considerando, juntamente com Ferreira (2010), que o ethos também é a imagem que o orador constrói dos outros no discurso, é importante mostrar aqui quais ethé são edificados para Ciça, especialmente com base nas apresentações da artista e/ou de suas obras. São informações que constam, portanto, das introduções de entrevistas; de prefácios, capas/contracapas de livros da artista; de comentários em obras teóricas sobre humor gráfico. Além das mesmas imagens reveladas nos discursos da própria Ciça, depreendem-se outras. 
No que concerne às características do trabalho como cartunista, Ciça é retratada, por diferentes olhares, como talentosa, criativa e séria. O talento pode ser visto nas considerações de Goidanich e Kleinert (2011, p. 95), na Enciclopédia dos quadrinhos, quando introduzem o verbete da artista: "Seu nome completo é tão comprido quanto o seu talento: Cecília Whitaker Vicente de Azevedo Alves Pinto". É por meio da figura retórica de comparação ("nome tão comprido quanto o seu talento") que os autores mostram a engenhosidade da artista.

A criatividade e a seriedade são destacadas, respectivamente, por Zélio (1986, p. 7) e por Ziraldo (1978, p. 3) ao se referirem à produção gráfica de Ciça: "trabalho criativo" e "Nós somos fãs incondicionais de sua 'patolândia' e achamos seu trabalho tão sério por seu humor de primeira qualidade". Nos dois casos, vê-se que marido e cunhado usam do lugar de qualidade para desvelar o ethos da cartunista (PERELMAN; OLBRECHTSTYTECA, 1996), visto que valorizam o único, o original.

$\mathrm{O}$ "humor de primeira qualidade" leva à construção do ethos da Ciça humorista. Além de crítica, irônica (aspectos mostrados nos discursos da própria artista), é perspicaz, inteligente, provocadora. Conforme destacam Goidanich e Kleinert (2011, p. 95), "Ciça, com patos, galinhas e um formigueiro, conseguiu, principalmente nos anos da ditadura militar, fazer uma síntese perfeita - e crítica - da realidade brasileira naquele duro período". Os temas eram sempre abordados com "ironia e bom humor", segundo Borges e Zouvi (2020, p. 17). Zélio (1986, p. 7), ao apresentar a obra dela, diz "me parece que a intenção da autora é precisamente [...] provocar. Ela pinça nas anotações feitas por seus personagens, quase quinhentos comentários, entre cerca de oito mil, feitos e publicados".

Vemos que Ciça é crítica e irônica, porque o bom humor exige uma dose de ironia e criticidade. É perspicaz e inteligente, porque suas tiras humorísticas fazem "uma síntese perfeita" da história e (realidade) política do país, na época da ditadura ou fora desse período ("pinça nas anotações feitas por seus personagens, quase quinhentos comentários, entre cerca de oito mil, feitos e publicados"). É provocadora, porque, além de incitar o leitor a refletir sobre a história do país, não "distrai da única preocupação: dizer alguma coisa, [...] o homem está sendo enganado" (KLINTOWITZ, 1978, p. 5).

Quanto ao estilo das produções de humor gráfico, nota-se que a leitura é unânime para os que comentam o modo como Ciça desenha ou produz: "Seu desenho simples e funcional complementa ideias ágeis, cheias de duplo sentido e consciência política" (BORGES; ZOUVI, 2020, p. 15) e "Seu traço é simples, as piadas ingênuas e concisas, a inteligência das tiradas e a sensibilidade logo chamaram a atenção dos leitores" (RIBEIRO, $1^{\text {o }}$ abr. 2008.). Os enunciados ressaltam traços como simplicidade, funcionalidade, ingenuidade, sensibilidade; o que leva aos seguintes ethé da Ciça desenhista: simples, funcional, ingênua e sensível.

Ainda em termos profissionais, Ciça é mostrada como perseverante e dedicada. Ethé que podem ser constados na fala de Ziraldo (1987, p. 3): “[...] há três mil e sessenta e cinco dias, com uma incrível assiduidade, ela vem inventando historinhas dos seus fascinantes personagens". Também é possível depreender imagens de engajada e conhecedora da situação política: "Do AI5 à Nova República, passando pela surpresa, pela euforia, pelo engodo, pelo terrorismo, pela censura, pelo autoritarismo, pelo túnel e 
vendo o arremedo de uma luz lá no fundo. Tudo isso foi anotado no diário dos personagens [...] publicados nos principais jornais do Brasil” (ZÉLIO, 1986, p. 7); "Vale dizer que essas tiras não estavam apenas em veículos da mídia tradicional. Eram presença cativa na imprensa alternativa, demarcando a posição antiditadura e antiautoritária da criadora" (BORGES; ZOUVI, 2020, p. 17).

Não desconsiderando a figura ilustre, é claro, é preciso também levar em conta a Ciça pessoa comum. A quarta capa da obra Pagando o pato (1986) traz a descrição de uma pessoa com uma vida comum, de rotina normal:

[...] paulista brasileira, maior de vinte e um, casada, mãe de três filhos. Vinte anos de quadrinhos, oito livros publicados, entre poesia, quadrinhos e livros infantis. Jornalista, ceramista, dona de casa, artista, cuida de dois gatos, dois cachorros e um papagaio. Também é feliz proprietária de uma jabuticabeira no quintal.

Para finalizar, destacamos dois ethé que, embora não estejam em oposição ou sejam contraditórios, são difíceis de serem observados num mesmo referente: ser referência ("notória") e ser pouco conhecida ("apagada"). Ainda que vista como referência na área de atuação - "um dos principais nomes do humor gráfico nacional" (CRESCÊNCIO, out. 2019); "[...] Um dos nomes mais expressivos de quadrinhos feitos por mulheres no Brasil" (ENTREVISTA - Ciça, 30 jan. 2014); "uma das mais importantes cartunistas brasileiras da história: riso fácil, jogos de palavras e politização - isso só para ficar nas qualidades do texto" (BORGES; ZOUVI, 2020, p. 16) -, é pouco conhecida - "Apesar de suas tiras estarem sendo publicadas em outros jornais brasileiros, em jornais da Suécia e da África do Sul - muita gente, fora de São Paulo, não conhece o mundo da Ciça" (ZIRALDO, 1978, p. 3).

Com base no exposto, ao olhar dos "outros", verifica-se que Ciça é mostrada com ethos de phrónesis e de areté, duas das disposições do bom orador, segundo Aristóteles (2015, 1996). Ao apresentarem o trabalho de Ciça, os autores destacam a sabedoria prática da cartunista (tanto pela organização dos desenhos quanto por ter, com eles, driblado a censura), por manifestar-se de forma competente e razoável. Destacam, portanto, a phrónesis ao comentarem que a artista:

a) "não utiliza o espaço da história em quadrinhos com a intenção de encurtar caminho: não há closes, zoom objetos destacados. Tudo se organiza segundo a mais clara das convenções. A sua tira obedece a narrativa de tempo tradicional. Há princípio, meio e fim, a articulação das figuras ocorre de maneira ordenada e a organização modesta pode enlouquecer o amante de sensações forte" (KLINTOWITZ, 1978, p. 4);

b) "Em uma época onde desenhar pessoas poderia ser arriscado e perigoso, a figura do pato foi uma boa saída para falar da política em época de ditadura" (Ladys Comics, 30 jan. 2014).

A areté, disposição que leva o homem a desempenhar a função com retidão e probidade, pode ser vista nos seguintes comentários sobre a cartunista: "Ciça [...] conseguiu [...] fazer uma síntese perfeita - e crítica - da realidade brasileira naquele duro período” (GOIDANICH; KLEINERT, 2011, p. 95); “[...] há três mil e sessenta e cinco 
dias, com uma incrível assiduidade, ela vem inventando historinhas dos seus fascinantes personagens, todos preocupados em entender, discutir e desancar as mentiras que procuraram nos impingir durante todos estes longos dias" (ZIRALDO, 1978, p. 3). Os autores ressaltam que Ciça cumpre sua proposta de forma honesta, com temperança e coragem: manifesta ethos de areté.

No que concerne aos ethé cômicos, aos olhos dos outros, nota-se que Ciça e seus quadrinhos apresentam as marcas do ironista (eíron). É o que destacam Ziraldo (1978, p. 3) em "muita gente [...] não conhece o mundo da Ciça nem a realidade cáustica, irônica, criativa, engraçadíssima" e Borges e Zouvi (2020, p. 17) em "não restaram temas tabu para a autora abordar, sempre usando-os com ironia e bom humor". Uma nota no Guia dos Quadrinhos, feita por Ribeiro ( $1^{\circ}$ abr. 2008), exibe outro tipo cômico da cartunista, o ingênuo (ágroikos), com destaque apenas paras as piadas, como se vê em: seu traço é "simples, as piadas ingênuas e concisas, a inteligência das tiradas e a sensibilidade logo chamaram a atenção dos leitores".

\section{CONSIDERAÇÕES FINAIS}

Esta exposição iniciou apontando uma contradição sobre Ciça. A desenhista é referência, mas pouco conhecida e pouco estudada. Havia informações pontuais sobre ela nos compêndios de quadrinhos e humor gráfico. Muito do que se sabia a respeito da autora era resultado do exposto em suas episódicas entrevistas. Uma das principais cartunistas do Brasil, como comumente se referem à criadora de "O Pato", era encoberta (nublada) na farta história sobre o tema. A proposta deste artigo foi, de alguma forma, buscar contribuir para o preenchimento dessa lacuna, procurando identificar marcas trazidas pela própria desenhista sobre as imagens que cria de si e também de como é vista por outros.

Para isso, foram analisadas as entrevistas concedidas por ela. Novo contraste: embora poucas, foram essenciais para a construção dos ethé da desenhista. Estes formam um perfil social de si, que inclui as atitudes, os costumes, as moralidades - todos elementos que aparecem na disposição do orador e que constituem sua historicidade. A historicidade demandou investigação na trajetória da produção gráfica da desenhista, tão vinculada às histórias em quadrinhos e ao humor.

Da investigação feita à criadora (via entrevistas e depoimentos sobre ela) e às criaturas (sua produção gráfica e humorística), pudemos lançar luzes mais precisas, com base na proposta de autores da Retórica e da Nova Retórica, tanto sobre as imagens que cartunista-oradora constrói de si quanto que os outros fazem dela.

No primeiro caso, pôde-se perceber que Ciça apresenta ethé de: cartunista espontânea, metafórica, crítica, politizada, desvalorizada financeiramente, requisitada; humorista crítica e irônica; escritora produtiva e aplicada; poetisa sensível e verborrágica; profissional autodidata, engajada e feminista; pessoa comum. Em suas enunciações, nota-se a oradora com as disposições de phrónesis (prudência), areté (sinceridade) e eúnoia (solidariedade). O ethos cômico construído por ela é o do eíron (ironista). 
No segundo caso, ou seja, no que se refere aos ethé edificados pelos outros sobre ela, Ciça é vista como: cartunista talentosa, criativa e séria; humorista crítica, irônica, perspicaz, inteligente, provocadora; desenhista simples, funcional, ingênua e sensível; profissional perseverante, dedicada, engajada e conhecedora da situação política. É uma referência, porém se mantém pouco conhecida. Ao olhar dos outros oradores, apresenta as disposições de phrónesis (prudência) e areté (sinceridade), bem como exibe traços de dois tipos de ethé cômicos, o eíron (ironista) e o agroikós (ingênuo).

Espera-se que esta exposição contribua para a necessária compreensão de uma autora tida como pioneira e de extrema relevância para a trajetória dos quadrinhos brasileiros e do humor produzido pela imprensa durante a segunda metade do século 20 . Trata-se de pessoa que se destacou em um ambiente duplamente desafiador: era dominado profissionalmente por homens e tinha pouco espaço para desenhistas nacionais. E tudo sob a sombra da censura imposta pelo período militar.

Entender melhor as imagens produzidas de/sobre Ciça é compreender também os diferentes ângulos do momento histórico de sua produção: o mercadológico, o relacionado à imprensa, ao humor gráfico, à política. Que este texto sobre Ciça seja um ponto de partida para mais estudos teóricos sobre a autora e suas criações. E que consigam ser tão críticos quanto a postura de "O Pato" e de sua autora.

\section{REFERÊNCIAS}

AMOSSY, R. Imagens de si no discurso: a construção do ethos. São Paulo: Contexto, 2005.

ANTOLOGIA brasileira de humor. Porto Alegre: L\&PM, 1976.

ARISTÓTELES. Ética a Nicômaco. Trad. de L. Vallandro e G. Bornheim. São Paulo: Nova Cultural, 1996.

ARISTÓTELES. Retórica. Trad. de M. A. Júnior, P. F. Alberto e A. N. Penal. São Paulo, Folha de S.Paulo, 2015.

BARALDI, M. Entrevista: Ciça (a primeira-dama do Cartum brasileiro). Bigorna, 18 jul. 2007.

Disponível em: https://www.bigorna.net/index.php?secao=entrevistas\&id=1184731251. Acesso em: 10 jun. 2020.

BORGES, T.; ZOUVI, A. Quem paga o pato. Revista Banda. São Paulo: Ugra Press, n. 2, p. 16-25, jan./fev. 2020 [Entrevista com Ciça].

CARMELINO, A. C. Retórica e humor gráfico: ethé dos fradinhos, de Henfil. Linguística, Montevideo, v. 34, n. 2, p. 81-97, 2018.

CIÇA. O pato no formigueiro. Rio de Janeiro: Codecri, 1979 (Coleção de humor do Pasquim, v. 4).

CRESCÊNCIO, C. L. É para rir ou para chorar? O riso feminista brasileiro em tempos de ditadura (19701980). História, histórias - Revista de pós-graduação em história da UNB, Brasília, v. 4, n. 7, p. 109-127, 2016.

CRESCÊNCIO, C. L. "Tá rindo de quê?” Ou os limites da teoria humor gráfico na imprensa Feminista do Cone Sul. Revista Territórios \& Fronteiras, Cuiabá, v. 10, n. 2, p. 75-92, ago./dez. 2017.

CRESCÊNCIO, C. L. Bia Sabiá em "o pessoal é político": (re)invenção do político no humor gráfico feminista de Ciça (Nós Mulheres, 1976-1978). Fronteiras: Revista de História, Dourados, MS, v. 20 , n. 35, p. 117-136, jan./jun. 2018.

CRESCÊNCIO, C. L. O humor mostra... como as coisas não devem ser": uma entrevista com Ciça, Revista Estudos Feministas, Florianópolis, vol. 27, n. 3, out. 2019. Disponível em:

http://www.scielo.br/scielo.php?script=sci_arttext\&pid=S0104-026X2019000300401. Acesso em: 10 jun. 2020.

CRESCÊNCIO, C. L.; DANTAS, É. Uma história do feminismo no Brasil por meio do humor gráfico (1976-1984). In: WOLFF, C. S.; ZANDONÁ, J.; MELLO, S. C. M. (Orgs.). Mulheres de luta: feminismo e esquerdas no Brasil (1964-1985). 1. ed. Curitiba: Appris, 2019. p. 254-279. 
DANTAS, D. F. Mulheres cartunistas: traços e rasuras nas fronteiras do estereótipo, Compós, s.d. Disponível em: <http://www.compos.org.br/data/biblioteca_829.pdf>. Acesso em: 10 jun. 2020.

ENTREVISTA - Ciça. Lady's Comics, 14 jan. 2014. Disponível em: http://ladyscomics.com.br/entrevista-cica. Acesso em: 10 jun. 2020.

FERREIRA, L. A. Leitura e persuasão: princípios de análise retórica. São Paulo: Contexto, 2010.

FERREIRA, L. A. Inteligência retórica e vocalidade: constituição e manutenção do ethos. In: FERREIRA, L. A. (Org.). Inteligência retórica: o ethos. São Paulo: Blucher, 2019. p. 9-23

FRYE, N. Anatomia da crítica: quatro ensaios. Trad. de M. Martini. São Paulo: É Realizações, 2013 (Coleção Crítica, história e teoria da literatura).

GOIDANICH, H. C.; KLEINERT, A. Enciclopédia dos quadrinhos. Porto Alegre, RS: L\&PM, 2011, p. 95.

KLINTOWITZ, J. Apresentação n. 2. In: CIÇA. O Pato, 10 anos. Rio de Janeiro: Codecri, 1978, p. 4-5.

MAGALHÃES, H. Humor em pílulas: a força criativa das tiras brasileiras. João Pessoa: Marca de Fantasia, 2006, p. 54-55.

MAIS Malditos Cartunistas - Ciça, YouTube, 16 abr. 2018. Disponível em:

https://www.youtube.com/watch?v=ArzBZOdxayI. Acesso em: 10 jun. 2020.

MARINO, D.; MACHADO, L. (Orgs.). Mulheres e quadrinhos: universidade. São Paulo: Skript, 2020.

MENDES, C. F. A gargalhada de Ulisses: a catarse na comédia. São Paulo: Perspectiva, 2008.

MEYER, M. A retórica. Trad. de M. N. Pires. São Paulo: Ática, 2007.

MORAES, A. SEVERINO, T. Entre patos e formigas, obra de Ciça compõe fábula política do Brasil, Folha, 100, Folha de S.Paulo, 21 fev. 2020. Disponível em: https://www1.folha.uol.com.br/folha-100anos/2020/02/entre-patos-e-formigas-obra-de-cica-compoe-fabula-politica-do-brasil.shtml. Acesso em: 10 jun. 2020.

MOYA, Á. de. História da história em quadrinhos. São Paulo: Brasiliense, 1993, p. 194.

MOYA, Á. de; CIRNE, M. Cronologia comentada das histórias em quadrinhos no Brasil. In: MOYA, Á.; CIRNE, M. et al. (Orgs.). Literatura em quadrinhos no Brasil: acervo da Biblioteca Nacional. Rio de Janeiro: Nova Fronteira: Fundação Biblioteca Nacional, 2002, p. 134.

NÓS MULHERES. Disponível em: https://www.fcc.org.br/conteudosespeciais/nosmulheres/. Acesso em: 10 jun. 2020.

PERELMAN, C.; OLBRECHTS-TYTECA, L. Tratado da argumentação: a nova retórica. São Paulo: Martins Fontes, 1996.

RIBEIRO, L. A. Ciça, Guia dos quadrinhos, $1^{\circ}$ abr. 2008. Disponível em: http://www.guiadosquadrinhos.com/artista/cica/4142. Acesso em: 27 jan. 2020.

SANTOS, R. E. O Brasil através das histórias em quadrinhos de humor. Cuaderno 74, Centro de Estudios en Diseno y Comunicación, 2019, p. 153-167.

SILVA, A. V. T. A. Imagem di/invertida: reflexões sobre a representação da mulher em tiras cômicas produzidas por mulheres no Brasil. JORNADAS INTERNACIONAIS DE HISTÓRIAS EM QUADRINHOS, 2., 2013, São Paulo. Escola de Comunicações e Artes. Anais ... São Paulo: Universidade de São Paulo, 2013. Disponível em:

http://www2.eca.usp.br/anais2ajornada/anais2asjornadas/Artigo_Alba_Valeria_Silva.htm. Acesso em: 10 jun. 2020.

TRAVAGLIA, L. C. O que é engraçado? Categorias do risível e o humor brasileiro na televisão. Estudos Linguísticos e Literários, v. 5-6, p. 42-79, 1989. Disponível em:

http://seer.ufal.br/index.php/revistaleitura/article/view/6579/5508. Acesso em: 10 jun. 2020.

ZÉLIO. In: CIÇA. Pagando o pato. São Paulo: Circo Editorial, 1986, p. 7.

ZIRALDO. Apresentação n. 1. In: CIÇA. O Pato, 10 anos. Rio de Janeiro: Codecri, 1978, p. 3.

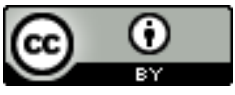

Este texto está licenciado com uma Licença Creative Commons Atribuição 4.0 Internacional. 